\title{
MORE THAN A STAGE: \\ DECOLONIZATION, ANAL SEX, AND \\ THE DIRTY EROTICS OF POWER IN \\ DELEUZE, GUATTARI, DEVEREUX, AND HERZOG
}

\section{TODD SHEPARD}

Department of History, Johns Hopkins University

E-mail: tshep75@jhu.edu

The footprint of Dagmar Herzog's scholarship has moved from Germany to the United States, then back again, before expanding outwards across Europe as well as to spaces drawn into Europe's orbit by conquest. Historically specific intersections between gender, religion, and politics are her specialty, with sexuality and sex as crucial sightlines in the constantly shifting landscapes that these always-moving parts compose. No historian currently writing in English on the late modern period, arguably, more acutely captures the intensity and conflicts that absorb individuals as well as larger groups as they live in and through these distinct topographies. This she does, in part, through the depth and the breadth of her research, which allow Herzog to reveal connections and disjunctures in ways that grab the reader's attention as well as explain the stakes. Her writings reveal an ability to listen to sources and care about what they intimate that is more often seen in certain scholars of the medieval or other exotic histories that rely on scarce or sketchy sources. For historians of the modern era, between the birth of ideology and ready access to endless and dense types of documentation, what Herzog continues to do is a revelation.

Her new book, Cold War Freud, maneuvers in the post-1945 spaces that Herzog has come to know so well. It homes in on a set of histories that offer new insights into psychoanalysis after Sigmund Freud (1856-1939) (and after the Shoah, World War II, and the birth of the Cold War, too) and allow Herzog to sound the depths of, as she puts it, "recurrent themes [that] all somehow involve desire, violence, and relations of power ... humans' struggle to 'mediat[e] between culture and 
the instinct"' (11). It is an evocative book, indeed. In early chapters, which explore US developments in the hothouse of the early Cold War, she shows how efforts by many psychoanalysts to depoliticize their claims often flattened their insights and eventually, and ironically, vitiated their influence on larger debates. Later chapters, on the 1960 and after, move to Germany, France, and West Africa, and also return to the US. They detail efforts to think about the new dynamics that anti-imperialism and the horrors of Cold War-stoked violence and dictatorships created. In this novel context, she draws readers' attention to critics who drew from psychoanalysis in order to rethink the very terms of politics, reflections that have given some quite radical psychoanalytic understandings and arguments new purchase across the world.

The evidence encompasses a wide range of the dense output of psychoanalysts and those inspired by psychoanalysis in multiple countries. The analyses navigate carefully and convincingly between the sexual, the political, and other factors, which creates space to think about numerous questions that other researchers will want to explore. One that drew my attention, as what follows sketches out, is the history of sex acts, a topic that has proven quite elusive. Perhaps because the rejection of stadial thinking is so important to Herzog, this book avoids explicit references to anality. In the evidence it deploys so incisively to position decolonization as central to its historical epoch, however, it offers up much evidence for how the politics of anal sex became newly potent in these years. Herzog's presentation of three widely cited French theorists-psychoanalyst Félix Guattari, his philosopher comrade Gilles Deleuze, and the anthropologist Georges Devereux - notably, pointedly, evokes how the dirty afterlives of empire shaped new thinking about power.

$* * *$

The Cold War offers a chronological frame to the histories Herzog examines. Yet this book has far more to say about the effects of anticolonialism and the challenges this worldwide movement posed to the actors (all of them from colonizing powers) and developments she investigates. The wide-scale decolonization of European colonies that took place across the globe in these years also produced foundational challenges to the intellectual and discursive structures that had undergirded modern empires. This was accentuated, as Herzog insists in her discussion of the birth of PTSD, by reactions to "one of the last great imperialist wars," that waged by the USA in Vietnam (121). Herzog's parsing out of psychoanalytic developments offers illuminating insight into the swirling intersections between sex and politics and desire and violence that questions and crises of empire thrust to the fore. 
The anticolonial frame she applies to the writings of Guattari and Deleuze brings particular clarity. Herzog emphasizes the underappreciated fact that, in the arguments they developed over the course of their jointly authored Anti-Oedipus, "nothing made the impoverishment of the traditional triadic psychoanalytic story clearer than a glance over the rim of the French hexagon." She quotes from the English translation: "It is strange that we had to wait for the dreams of colonized peoples in order to see that, on the vertices of the pseudo-triangle, mommy was dancing with the missionary, daddy was being fucked by the tax collector, while the self was being beaten by a white man." As Herzog writes, "the footnote that followed was to [Frantz] Fanon" (167). As Herzog reads the "schizoanalytic" arguments of Deleuze and Guattari, what they took from Fanon and from "the lessons of colonialism and anticolonial struggles" was greater than simply that "the colonial experience showed the limits of traditional psychoanalytic theorizing. Families are filled with gaps and transected by breaks that are not familial," Herzog insists. She identifies some of the key modern historical events that produced such "breaks": "the Commune, the Dreyfus Affair, religion and atheism, the Spanish Civil War, the rise of fascism, Stalinism, the Vietnam war, May '68-all these things form complexes of the unconscious, more effective than everlasting Oedipus" (168). Politics was foundational. As she explains, Guattari and Deleuze "called [their approach] 'schizoanalysis' not because they romanticized madness - a misunderstanding they continually had to refute-but in order to call attention to the craziness in the world that required assessment as much as or more than individual craziness." Anticolonial politics efficiently made this craziness visible.

What more do we learn, however, when we turn back to the French-language quotation about "the vertices of the pseudo-triangle," and realize that "daddy" was not just being "fucked" but "fucked up the ass" (the quite direct French formulation is se faisait enculer)? In Deleuze and Guattari's original French text, instances of the verb form enculer appear five times, and each does crucial critical work. Of particular interest, some instances name one connection in a string of parallel connections between people in which each, Deleuze and Guattari argue, needs to be understood in libidinal terms; the ass-fucking, however, is the only connection that is self-evidently sexual ("mommy was dancing with the missionary, daddy was being [ass-] fucked by the tax collector, while the self was being beaten by a white man"). In another key instance, which captures what Herzog highlights about the critique Deleuze and Guattari offer of the "familial," they wrote that "être enculé par le socius, désirer être enculé par le socius, ne dérive pas du père et de la mère, bien que le père et la mère y aient leur rôle comme agents subalternes de transmission ou d'exécution." The translation here, even more so than in the previous example, obfuscates the anal: "being fucked by the socius, wanting to be fucked by the socius, does not derive from the father and 
mother, even though the father and mother have their roles there as subordinate agents of transmission or execution." Oddly, no subsequent critic has commented on the text's use of this term, or its mistranslation into English. ${ }^{1}$

The use Deleuze and Guattari made of enculer was symptomatic of a larger phenomenon. In Volonté de savoir (1976) Michel Foucault, in his much-discussed analyses of "sodomy" and the "sodomite," moved beyond the interest he had shown in the figure of the sodomite, already evoked in his Folie et déraison (1961) and in subsequent work on madness. The first volume of his History of Sexuality was also his first important effort to reflect on the act of sodomy. Note that, in the very years when Foucault formulated his much-cited description of the act of sodomy as "that utterly confused category" ("cette catégorie si confuse"), sodomy increasingly came, quite clearly, to mean anal sex. The philosopher turned to the act in a context in which, on the one hand, many historians had turned to sodomy to describe past instances of homosexuality and, on the other, numerous commentators (Guattari, Deleuze, and Foucault among them) came to see this act as a powerful tool to rethink understandings of power.

In the 1960s and 1970s, a new generation of scholars used the records of (secular and ecclesiastical) condemnations of "sodomy" to give homosexuals a history. ${ }^{2}$ The presumption that guided their research was that sodomy encompassed homosexuality. While much of this work traced direct lines between acts and male homosexual identities, a more sophisticated discussion also emerged. These scholars distinguished between those condemnations of sodomy in the past that targeted acts and those that spoke of same-sex, largely male-male sexual relationships. In the 1970s, the most careful historical scholarship on such

$1 \quad$ Gilles Deleuze and Félix Guattari, L'anti-Oedipe: Capitalisme et schizophrénie, augmented new edn (Paris, 1972), 73, 415, 348. In each instance the English translation offered in Anti-Oedipus: Capitalism and Schizophrenia, trans. Robert Hurley, Mark Seem, and Helen R. Lane, with a Preface by Michel Foucault (Minneapolis, 1983), is a form of "to fuck": 82, 347, 293. On "socius" see Daniel Smith and John Protevi, "Gilles Deleuze," The Stanford Encyclopedia of Philosophy (Spring 2013 edn), ed. Edward N. Zalta, at http://plato.stanford.edu/archives/spr2013/entries/deleuze, accessed 12 Dec. 2014. Many scholars, notably queer theorists, have commented on a 1973 Deleuze letter, in which the English translation of enculage was the more accurate "ass-fuck." See Gilles Deleuze, "Letter to a Harsh Critic," in Deleuze, Negotiations 1972-1990, trans. Martin Joughin (New York, 1995), 11-12.

2 See e.g. J. Bottéro and H. Petschow, "Homosexualität," in Erich Eberling and Bruno Meissner, eds., Reallexikon der Assyriologie (Berlin, 1981) 459-468, at 467; E. W. Monter, "La sodomie à l'époque moderne en Suisse romande," Annales H.S.S. 29/4 (1974), 1023-33; for a particularly evocative analysis that links sodomy, homosexuality, and violence see the discussion of Rousseau's writing on sexual initiation and masculine friendship in Madeleine Anjubault Simon, Amitié et passion: Rousseau et Sauttersheim (Geneva, 1972), 89-95. 
questions increasingly shifted focus from a historicization of the sodomitical writ large onto penetrative anal sex. The obvious example is Kenneth J. Dover, whose Greek Homosexuality Foucault invoked as crucial grounding for his work on sodomy. Dover's scholarship on ancient Greece had begun to focus on "malemale sex from the mid-196os," classicist John Davidson argues, "when he began to challenge the silences and soft-peddling of previous analyses," which spoke of "loving male friendships and insisted that these be recognized as sexual in nature, with one (older) male as the dominant partner and the other younger male as submitting to him." From 1974 on, however, Dover became much more explicit: it was not the broader category of male-male sexual interactions nor even of male "passivity" that was the focus of ancient Greek concern and taboo: it was quite specifically males who were anally penetrated. As one commentator puts it, by 1978 and the publication of Greek Homosexuality, Dover "had put sex at the heart of Greek homosexuality, and rear entry at the centre of Greek anxieties about sex." Foucault embraced his work. ${ }^{3}$

Which brings us to "anthropologist and analyst George Devereux," one of the many key players in Cold War Freud. Devereux, Herzog notes, was a founding figure and the coiner of the term "ethnopsychoanalysis," an approach at the center of the book's final chapter, "Ethnopsychoanalysis in the Era of Decolonization." Herzog finds Devereux compelling on multiple levels; as with Guattari, she is particularly interested in his radical challenge to the Oedipal triangle. "Devereux flipped it," Herzog argues, "to emphasize that both the brutally murderous and the taboo-breaking sexually covetous impulses originated from the parents, not the children." She approvingly notes that "Devereux also questioned the heterosexual framing Freud had given the story, recovering violent same-sex desires in earlier versions of the myth" (190). ${ }^{4}$ Rather than desire, several scholars have instead foregrounded the extensive writing that Devereux did on samesex acts, which directly shaped Dover's interpretations in Greek Homosexuality and, thus, those Foucault advanced in History of Sexuality, volume 1. As the classicist Thomas Hubbard summarized the argument, "Dover's preoccupation with physical sex and the shamefulness of being sexually passive" was due "to the influence of his collaboration with the notoriously homophobic ethnopsychoanalyst Georges Devereux, who labeled the Greek practice 'pseudohomosexuality' - all a matter of acts rather than perverted orientation, and thus

James Davidson, "Dover, Foucault and Greek Homosexuality: Penetration and the Truth of Sex," Past \& Present 170/1 (Feb. 2001), 3-51, at 14.

$4 \quad$ George Devereux, "Why Oedipus Killed Laius: A Note on the Complementary Oedipus Complex in Greek Drama," International Journal of Psycho-analysis 34/2 (1953), 132-41. 
in Devereux' clinical view less pathological." ${ }^{\prime}$ The debates among classicists cited here, it must be emphasized, are quite intense and also, in many ways, emblematic of the deeply learned and empathetic work, referenced in the opening paragraph of this essay, anchored in a source base that, at least to the eyes of scholars of the late modern era, is scanty indeed.

The evidence I have assembled here, drawn from Cold War Freud and elsewhere, suggests that, over the course of the 1960s and, especially, the 1970s, anal sex as metaphor came to seem mutable and potent. What emerged, I have argued elsewhere, was a deeply ambiguous, yet densely productive, site of meaning, where it seemed possible to analyze post-decolonization (and postcolonial) specters of violence, shame, and sex both together and to political ends. This is not Herzog's remit. Yet, I am certain, this type of work is one of many new ways to think about the Cold War era that this book will spark or catalyze. ${ }^{6}$

5 Review: "Greek Love: Thomas K. Hubbard on Davidson; Lear \& Cantarella," H-Histsex (Feb. 2009), at http://h-net.msu.edu/cgi-bin/logbrowse.pl?trx=vx;list=HHistsex;month=0902;week=b;msg=Ug\%2BYuljwHAbsmjyw\%2BhMXhQ, accessed 4 March 2018.

6 See Todd Shepard, Sex, France, and Arab Men, 1962-1979 (Chicago, 2017), esp. chap. 7, "Power, Resistance, and Sodomy in Post-Algerian France," 196-225. 